\title{
Ancaman Zoonosis : Infeksi Plasmodium knowlesi pada Manusia
}

\section{Zoonotic Threat: Plasmodium knowlesi Infection in Humans}

\author{
Dewi Saroh ${ }^{1 *}$, Dwi Haryatmi² \\ dewisaroh27@gmail.com \\ 1,2Program Study D-III Analis Kesehatan, STIKES Nasional
}

\begin{abstract}
Abstrak
Plasmodium knowlesi merupakan salah satu protozoa darah yang dapat menyebabkan penyakit malaria. $P$. knowlesi pada awalnya hanya menginfeksi monyet ekor panjang, namun saat ini dapat menyebabkan zoonosis dan menginfeksi manusia. $P$. knowlesi dapat menginfeksi tubuh manusia secara tunggal ataupun mix-infection dengan parasit lain. Tulisan ini bertujuan untuk memberikan review terkait morfologi, prevalensi, diagnosis, dan pengobatan dari infeksi $P$. knowlesi. Hasil dari review didapatkan bahwa diagnosis $P$. knowlesi dapat ditegakkan dengan pemeriksaan PCR karena diagnosis secara mikroskopis dapat menimbulkan mis-identification sehingga menyebabkan kesalahan dalam diagnosis. Penularan $P$. knowlesi ke manusia dapat terjadi melalui gigitan nyamuk Anopheles Leucosphyrus Group. Prevalensi $P$. knowlesi hingga saat ini banyak ditemukan di wilayah Asia Tenggara khususnya di Malaysia. Pengobatan malaria akibat P. knowlesi tanpa komplikasi dapat diberikan dengan terapi ACT atau dengan kombinasi klorokuin dan primakuin.
\end{abstract}

Keywords: $P$. knowlesi, prevalensi, faktor resiko, diagnosis, zoonosis.

\begin{abstract}
Plasmodium knowlesi is one of the blood protozoa that can cause malaria. P. knowlesi initially only infected long-tailed macaques, but now it can cause zoonoses and infect humans. P. knowlesi can infect human body singly or mix infection with other parasites. This paper aims to provide a review of the morphology, prevalence, diagnosis, and treatment of $P$. knowlesi infections. The results of the review found that diagnosis of $P$. knowlesi can be established by PCR examination because diagnosis by microscopic can cause misidentification and lead to errors in diagnosis. Transmission of $P$. knowlesi to humans can occur through the bite of Anopheles Leucosphyrus Group mosquito. The prevalence of $P$. knowlesi to date has been found in the Southeast Asian region specifically in Malaysia. Treatment of malaria due to $P$. knowlesi without complications can be given with ACT therapy or with a combination of chloroquine and primaquine.
\end{abstract}

Keywords: P. knowlesi, prevalence, risk factor, diagnosis, zoonosis. 


\section{Pendahuluan}

Plasmodium sp. merupakan salah satu jenis protozoa darah yang dapat menyebabkan malaria, baik malaria pada manusia maupun malaria pada hewan. Pada tahun 2004 dan sebelumnya, malaria pada manusia hanya disebabkan oleh empat jenis spesies saja yaitu Plasmodium falciparum, Plasmodium vivax, Plasmodium ovale, dan Plasmodium malariae. Namun pada akhir tahun 2004 tercatat adanya kasus infeksi Plasmodium knowlesi pada manusia (Siner et al., 2017 dan Baird, 2009). P. knowlesi merupakan salah satu spesies Plasmodium sp. yang dapat menyebabkan infeksi malaria pada primata. Spesies primata yang dapat menjadi host bagi $P$. knowlesi diantaranya yaitu Macaca fascicularis, Macaca nemestrina, dan Macaca leonine. Sedangkan vektor infeksi tersebut yaitu dari nyamuk Anopheles Leucosphyrus Group (Zaw and Lin, 2019).

Infeksi P. knowlesi memiliki spektrum yang luas dan dapat menimbulkan infeksi yang fatal, meskipun demikian infeksi $P$. knowlesi bersifat asymptomatis dan submikroskopis pada semua kelompok umur. P. knowlesi pertama kali menginfeksi pada manusia terjadi di Serawak Malaysia dan saat ini kasus infeksi P. knowlesi telah tercatat di wilayah Asia Tenggara diantaranya yaitu Malaysia, Thailand, Philiphina, Singapura, Myanmar, Cambodia, Laos, Vietnam, Pulau Andaman dan Nicobar India dan Indonesia (Siner et al., 2017; Lubis et al., 2017; dan Moyes et al., 2014). Di negara Indonesia kasus P. knowlesi pernah ditemukan di Kalimantan, Aceh, dan Borneo. Hingga saat ini meskipun telah ditemukan kasus $P$. Knowlesi di Indonesia, tetapi belum banyak dilakukan penelitian terkait kasus tersebut. Saat ini penyakit akibat zoonosis lebih dikenal dengan penyakit yang berbahaya karena sulit untuk dikendalikan dan system pengendaliannya harus mencakup dua hospes yaitu pada manusia dan hewan. Selain itu zoonosis juga sangat ditakuti karena dapat menyebabkan kematian dan kerugian ekonomi yang sangat besar (Baraniah, 2005). Mengingat bahaya dari infeksi zoonosis dan banyaknya ditemukan kasus baru $P$. knowlesi maka penulis tertarik untuk membuat review dengan tujuan menjelaskan lebih detail mengenai morfologi, siklus hidup, prevalensi, diagnosis, co-infeksi $P$. knowlesi, faktor resiko, dan pengobatannya.

\section{Metode Penelitian}

Tulisan ini merupakan hasil dari abstraksi dan sintesis terkait $P$. knowlesi yang diperoleh dari berbagai sumber, seperti buku, jurnal dalam negeri maupun luar negeri, dan dari web page. Pencarian informasi tersebut menggunakan kata kunci $P$. knowlesi, prevalensi P. knowlesi, faktor resiko $P$. knowlesi, dan zoonosis $P$. knowlesi.

\section{Pembahasan}

\section{Morfologi Plasmodium knowlesi}

$P$. knowlesi termasuk dalam filum Protozoa, Subfilum Apicomplexa, Kelas Sporozoa, dan Genus Plasmodium (Zaman, 1997). Morfologi dari P. knowlesi terdiri atas sporozoit, merozoit, tropozoid, skizon, dan gametosit. Gambaran morfologi pada tiap stadium dari $P$. knowlesi memiliki kesamaan dengan P. falciparum dan P. malariae (Siner et al., 2017 dan Lubis et al., 2017). Pada stadium merozoit (stadium ring) P. knowlesi memiliki morfologi yang sama seperti P. falciparum yang ditandai dengan ditemukannya titik kromatin ganda, infeksi multiple per eritrosit, dan tidak adanya pembesaran sel darah merah yang terinfeksi. Sedangkan pada stadium tropozoit P. knowlesi memiliki morfologi yang sama seperti $P$. malariae yaitu bentuk tropozoit seperti pita. Persamaan morfologi tersebutlah yang menjadi kelemahan dalam identifikasi dan diagnosis malaria akibat $P$. knowlesi. Selain itu pada kasus $P$. knowlesi gejala demam muncul per 27 jam meskipun parasitemia rendah dan tidak terdeteksi secara mikroskopis (Piera et al., 2017 dan Paisal \& Indriyati, 2014).

\section{Siklus Hidup Plasmodium knowlesi}

Siklus hidup dari semua parasit pada malaria pada umumnya sama, terdiri dari dua fase yaitu fase seksual yang terjadi pada nyamuk (sporogoni) dan fase aseksual yang terjadi pada manusia (skizogoni). 


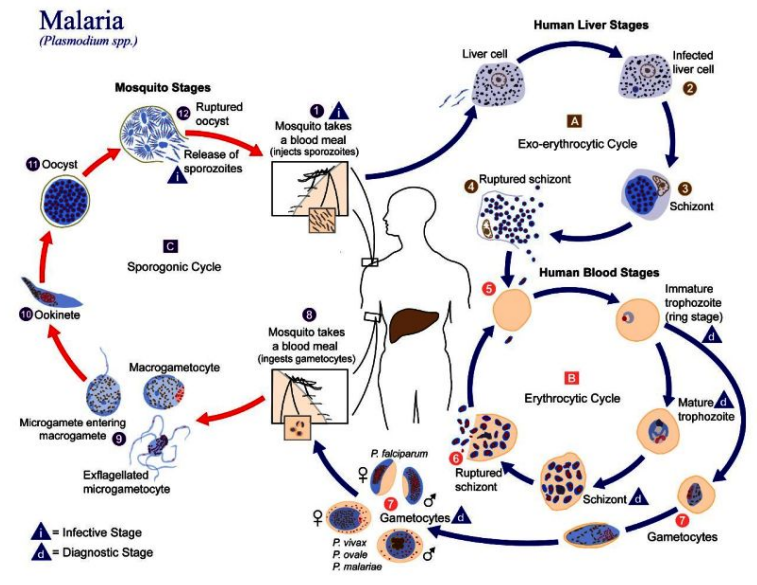

Gambar 1. Siklus hidup Plasmodium sp. secara umum (CDC, 2018)
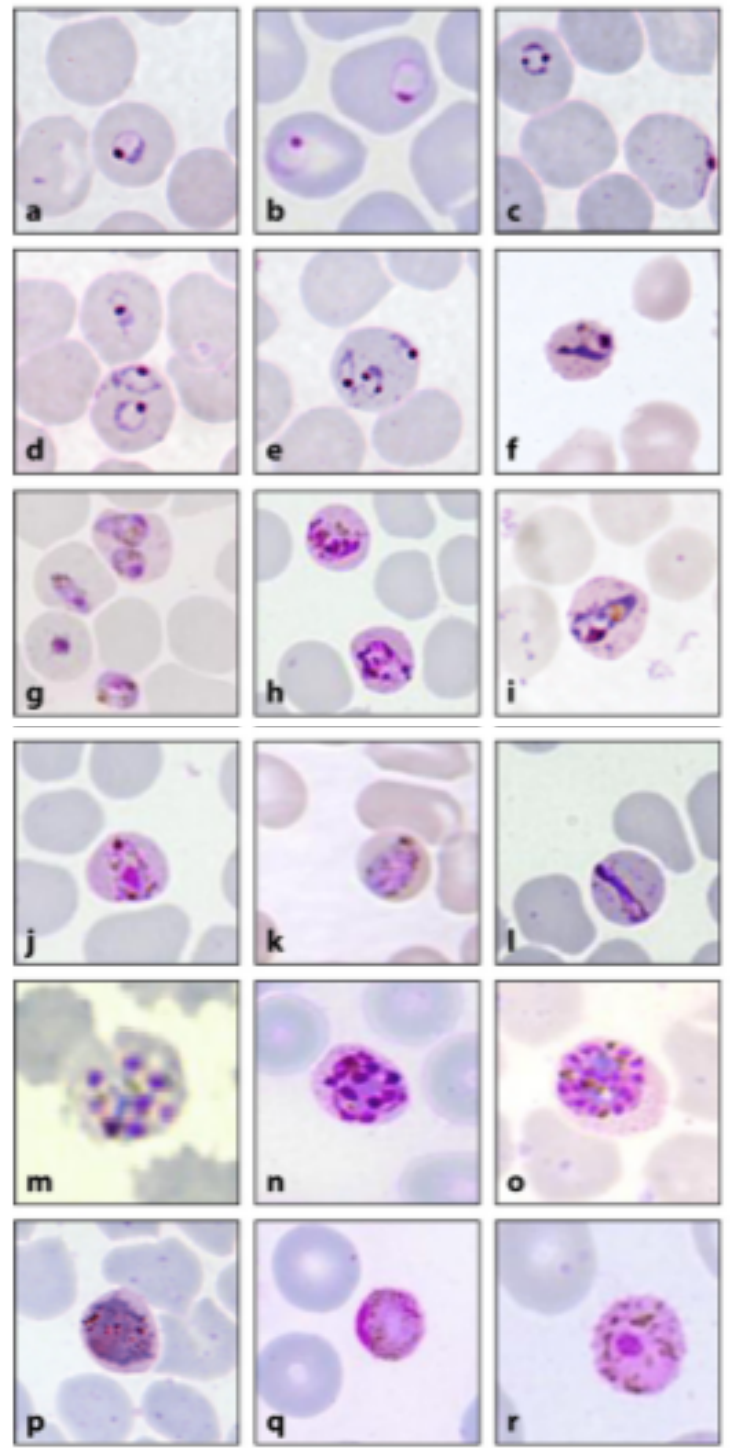

Gambar 1. Morfologi P. knowlesi dilihat secara mikroskopis (Cox-Singh, 2008 dan Lee et al. 2009)
Infeksi Plasmodium sp. dimulai saat terjadinya gigitan nyamuk Anopheles sp. betina yang terinfeksi Plasmodium sp. Sporozoit yang dibawa oleh nyamuk selanjutnya akan memasuki hepatosit dan terjadilah fase aseksual (skizon jaringan) membentuk skizon praeritrositik. Pada stadium skizon pra-eritrositik ini tidak menimbulkan gejala apapun. Stadium selanjutnya yaitu lepasnya merozoit ke dalam aliran darah dan menembus eritrosit, pada stadium ini disebut juga dengan periode prapaten dengan masa inkubasi sekitar 12 hari untuk P. falciparum dan P. knowlesi, 14 hari untuk $P$. vivax dan $P$. ovale, serta 30 hari untuk P. malariae. Selanjutnya merozoit berkembang hingga stadium skizon darah dan kemudian skizon tersebut akan pecah dan melepaskan merozoit untuk menginfeksi eritrosit yang baru. Pada fase ini ditandai dengan munculnya demam yang persisten (24 jam untuk $P$. knowlesi, 48 jam untuk P. falciparum, P. vivax, $P$. ovale, dan 72 jam untuk P. malariae). Selain munculnya demam, juga terjadi pelepasan sitokin dari makrofag sehingga menimbulkan peningktan suhu tubuh. Merozoite yang tidak menginfeksi eritrosit akan berkembang menjadi gametosit yang siap untuk dihisap oleh nyamuk untuk melanjutkan fase seksual (CDC, 2018 dan Ministri of Health Malaysia, 2013).

\section{Prevalensi dan Faktor Resiko Plasmodium knowlesi}

Prevalensi P. knowlesi berbeda-beda pada setiap negara endemik. Prevalesi P. knowlesi paling tinggi terjadi di negara Malaysia, yang mana di negara tersebut kasus $P$. knowlesi pada manusia pertama kali ditemukan. Hingga saat ini kasus P. knowlesi masih banyak ditemukan di Malaysia khususnya di Malaysia Borneo dan Peninsular Malaysia. Hal tersebut berhubungan dengan geografis daerah tersebut yang sebagian besar berupa hutan hujan tropis (Singh et al., 2004). Prevalensi P. knowlesi berdasarkan usia dari berbagai penelitian menunjukkan bahwa infeksi $P$. knowlesi lebih banyak terjadi pada orang dewasa. Hal ini dikarenakan pada orang dewasa banyak melakukan aktivitas di daerah dekat hutan ataupun banyak aktivitas yang dilakukan malam hari diluar rumah sehingga mendapatkan paparan dan kontak langsung lebih banyak (Piera et al., 2017 dan Grigg et al., 2017). Penularan secara langsung dari manusia ke manusia hingga saat ini belum dilaporkan. 


\section{Diagnosis Plasmodium knowlesi}

Diagnosis malaria dapat dilakukan dengan pemeriksaan gold standart yaitu pemeriksaan mikroskopis. Pemeriksaan secara mikroskopis dapat dilakukan dengan dua cara yaitu perhitungan per seribu eritrosit untuk pemeriksaan apusan darah tipis dan perhitungan per dua ratus leukosit untuk pemeriksaan apusan darah tebal.

Pemeriksaan mikroskopis pada apusan darah tipis menurut Harijanto (2000).

Derajat Parasitemia $=\frac{\text { Jumlah eritrosit terinfeksi }}{1000 \text { eritrosit }} \times 100 \%$

Tabel 1. Prevalensi P. knowlesi

\begin{tabular}{|c|c|c|c|c|c|c|c|c|}
\hline \multirow[b]{2}{*}{ Penulis } & \multirow[b]{2}{*}{ Tahun } & \multirow[b]{2}{*}{ Lokasi } & \multirow[b]{2}{*}{ Subyek } & \multirow[b]{2}{*}{$\begin{array}{l}\text { Jumlah } \\
\text { Sampel }\end{array}$} & \multicolumn{3}{|c|}{ Prevalensi $P$. knowlesi } & \multirow[b]{2}{*}{ Faktor Resiko } \\
\hline & & & & & $\begin{array}{l}\text { Total } \\
(\%)\end{array}$ & $\begin{array}{l}\text { Usia } \\
\text { (tahun) }\end{array}$ & $\begin{array}{l}\text { Jenis } \\
\text { Kelamin }\end{array}$ & \\
\hline Singh et al. & 2004 & $\begin{array}{l}\text { Kapit, } \\
\text { Sarawak } \\
\text { Malaysia } \\
\text { Borneo }\end{array}$ & Pasien & 208 & Pk. 58 & $\begin{array}{l}\text { Dewasa } \\
(>15 \\
\text { tahun) }\end{array}$ & $\begin{array}{l}\mathrm{L}: 67 \\
\mathrm{P}: 33\end{array}$ & $\begin{array}{l}\text { Penebang hutan, } \\
\text { Petani, } \\
\text { Perburuan }\end{array}$ \\
\hline $\begin{array}{l}\text { Vythilingam } \\
\text { et al. }\end{array}$ & 2008 & $\begin{array}{l}\text { Peninsular } \\
\text { Malaysia }\end{array}$ & Pasien & 111 & $\begin{array}{l}P k . \\
69,37\end{array}$ & - & - & - \\
\hline $\begin{array}{l}\text { Putaporntip } \\
\text { et al. }\end{array}$ & 2009 & Thailand & Pasien & 1874 & $\begin{array}{l}\text { Co-Pk. } \\
0,57\end{array}$ & $\begin{array}{l}1-81 \\
\text { tahun }\end{array}$ & $\begin{array}{l}\mathrm{L}: 8 \\
\mathrm{P}: 2\end{array}$ & - \\
\hline $\begin{array}{l}\text { Pongvongsa } \\
\text { et al. }\end{array}$ & 2018 & $\begin{array}{l}\text { Perbatasan } \\
\text { Laos dan } \\
\text { Vietnam }\end{array}$ & $\begin{array}{c}\text { Masyara } \\
\text { kat }\end{array}$ & 130 & $\begin{array}{l}\text { Co-Pk. } \\
9,23\end{array}$ & $\begin{array}{l}\leq 5: 7 \\
6-14: \\
4 \\
\geq 15: 1\end{array}$ & $\begin{array}{l}\mathrm{L}: 7 \\
\mathrm{~F}: 5\end{array}$ & - \\
\hline $\begin{array}{l}\text { Sermwittaya } \\
\text { wong et al. }\end{array}$ & 2012 & $\begin{array}{l}\text { Thailand \& } \\
\text { Myanmar }\end{array}$ & Pasien & 419 & $\begin{array}{l}P k . \\
0,48\end{array}$ & $\begin{array}{l}45: 1 \\
30: 1\end{array}$ & $\mathrm{~L}: 2$ & $\begin{array}{l}\text { Petani } \\
\text { perkebunan, } \\
\text { nelayan }\end{array}$ \\
\hline $\begin{array}{l}\text { Marchand et } \\
\text { al. }\end{array}$ & 2011 & $\begin{array}{l}\text { Vietnam } \\
\text { Selatan }\end{array}$ & $\begin{array}{l}\text { Pekerja } \\
\text { Hutan }\end{array}$ & 549 & $\begin{array}{l}\text { ACD : } \\
15 \\
\text { CSS : } \\
51\end{array}$ & $\begin{array}{l}\text { Semua } \\
\text { umur }\end{array}$ & $\begin{array}{l}\text { ACD } \\
\text { L }: 8 \\
P: 5 \\
\text { CSS } \\
L: 12 \\
P: 7\end{array}$ & $\begin{array}{l}\text { Masyarakat yang } \\
\text { hidup di dekat } \\
\text { hutan }\end{array}$ \\
\hline Siner et al. & 2017 & $\begin{array}{l}\text { Betong, } \\
\text { Sarawak } \\
\text { Malaysia } \\
\text { Borneo }\end{array}$ & $\begin{array}{c}\text { Pendud } \\
\text { uk } \\
\text { rumah } \\
\text { panjang }\end{array}$ & 555 & $\begin{array}{l}P k . \\
0,37\end{array}$ & Dewasa & $\begin{array}{l}\mathrm{L}: 267 \\
\mathrm{P}: 288\end{array}$ & $\begin{array}{l}\text { Petani, Nelayan, } \\
\text { Pekerja Kebun }\end{array}$ \\
\hline Lubis et al. & 2017 & $\begin{array}{l}\text { Sumatera } \\
\text { Utara, } \\
\text { Indonesia } \\
\text { (Batubara, } \\
\text { Langkat, } \\
\text { Nias } \\
\text { Selatan) }\end{array}$ & Pasien & $\begin{array}{c}3731 \\
\text { Batubara : } \\
1270 \\
\text { Langkat : } \\
544 \\
\text { Nias } \\
\text { Selatan : } \\
1917 \\
\end{array}$ & $\begin{array}{l}\text { Pk. } \\
6,80\end{array}$ & $\begin{array}{l}<5: 28 \\
5-14: \\
96 \\
>\quad 15: \\
130\end{array}$ & $\begin{array}{l}\mathrm{L}: 125 \\
\mathrm{P}: 129\end{array}$ & - \\
\hline Piera et al. & 2017 & $\begin{array}{l}\text { Sabah, } \\
\text { Malaysia }\end{array}$ & Pasien & 73 & $\begin{array}{l}P k . \\
69,4\end{array}$ & Dewasa & $\begin{array}{l}\mathrm{L}: 38 \\
\mathrm{P}: 12\end{array}$ & - \\
\hline Grigg et al. & 2017 & $\begin{array}{l}\text { Sabah, } \\
\text { Malaysia }\end{array}$ & Pasien & 320 & $\begin{array}{l}\text { Pk. } \\
71,5\end{array}$ & $\begin{array}{l}\text { Dewasa } \\
(\geq 15: \\
208)\end{array}$ & $\begin{array}{l}\mathrm{L}: 174 \\
\mathrm{P}: 55\end{array}$ & $\begin{array}{l}\text { Petani, pekerja } \\
\text { kelapa sawit, } \\
\text { penebang hutan, } \\
\text { kontak langsung } \\
\text { dengan monyet, } \\
\text { travel overnight. }\end{array}$ \\
\hline
\end{tabular}


Tabel 2. Diagnosis P. Knowlesi

\begin{tabular}{|c|c|c|c|c|c|c|c|c|}
\hline \multirow{2}{*}{ Penulis } & \multirow{2}{*}{ Tahun } & \multirow{2}{*}{ Lokasi } & \multirow{2}{*}{ Subyek } & \multirow{2}{*}{$\begin{array}{l}\text { Jumlah } \\
\text { Sampel }\end{array}$} & \multirow{2}{*}{ Diagnosis } & \multirow{2}{*}{$\begin{array}{c}\text { Metode } \\
\text { Diagnosis }\end{array}$} & \multicolumn{2}{|c|}{ Sampel Positif } \\
\hline & & & & & & & Mikrokopis & Molekuler \\
\hline Singh et al. & 2004 & $\begin{array}{l}\text { Kapit, } \\
\text { Serawak } \\
\text { Malaysia }\end{array}$ & Pasien & 208 & $\begin{array}{l}\text { Mikroskopis } \\
\text { Molekuler }\end{array}$ & $\begin{array}{l}\text { Apusan } \\
\text { tebal dan } \\
\text { apus tipis } \\
\text { (Giemsa) } \\
\text { Nested } \\
\text { PCR }\end{array}$ & $\begin{array}{l}P f: 25 \\
P m: 141 \\
P v: 42\end{array}$ & Pk: 120 \\
\hline $\begin{array}{l}\text { Vythilingam } \\
\text { et al. }\end{array}$ & 2008 & $\begin{array}{l}\text { Peninsular } \\
\text { Malaysia }\end{array}$ & Pasien & 111 & $\begin{array}{l}\text { Mikroskopis } \\
\text { Molekuler }\end{array}$ & $\begin{array}{l}\text { Apusan } \\
\text { tebal dan } \\
\text { apus tipis } \\
\text { (Giemsa) } \\
\text { Nested } \\
\text { PCR }\end{array}$ & $\begin{array}{l}P f: 6 \\
P v: 9 \\
P m: 93 \\
P f+P m: 1 \\
P m+P v: 2\end{array}$ & Pk. 77 \\
\hline $\begin{array}{l}\text { Putaporntip } \\
\text { et al. }\end{array}$ & 2009 & Thailand & Pasien & 1874 & $\begin{array}{l}\text { Mikroskopis } \\
\text { Molekuler }\end{array}$ & $\begin{array}{l}\text { Apus tebal } \\
\text { dan apus } \\
\text { tipis } \\
\text { (Giemsa) } \\
\text { Nested } \\
\text { PCR }\end{array}$ & $\begin{array}{l}P f: 679 \\
P v: 1013 \\
P m: 3 \\
P o: 0 \\
P f+P v: 8 \\
(-): 48\end{array}$ & Pk: 10 \\
\hline $\begin{array}{l}\text { Pongvongsa } \\
\text { et al. }\end{array}$ & 2018 & $\begin{array}{l}\text { Perbatasan } \\
\text { Laos dan } \\
\text { Vietnam } \\
\end{array}$ & $\begin{array}{l}\text { Masyara } \\
\text { kat }\end{array}$ & 130 & Molekuler & PCR & - & $\begin{array}{l}P v+P k: 5 \\
P f+P v+ \\
P k: 7\end{array}$ \\
\hline $\begin{array}{l}\text { Sermwitta } \\
\text { yawong et } \\
\text { al. }\end{array}$ & 2012 & $\begin{array}{l}\text { Thailand } \\
\& \\
\text { Myanmar }\end{array}$ & Pasien & 419 & $\begin{array}{l}\text { Mikroskopis } \\
\text { Molekuler }\end{array}$ & $\begin{array}{l}\text { Apus tebal } \\
\text { dan apus } \\
\text { tipis } \\
\text { (Giemsa) } \\
\text { Nested } \\
\text { PCR }\end{array}$ & $\begin{array}{l}\text { Thailand } \\
P f: 69 \\
P v: 102 \\
\text { Myanmar } \\
P f: 121 \\
P v: 123 \\
P f+P v: 4\end{array}$ & $P k: 2$ \\
\hline $\begin{array}{l}\text { Marchand } \\
\text { et al. }\end{array}$ & 2011 & $\begin{array}{l}\text { Vietnam } \\
\text { Selatan }\end{array}$ & $\begin{array}{l}\text { Pekerja } \\
\text { Hutan }\end{array}$ & 549 & $\begin{array}{l}\text { Mikroskopis } \\
\text { Molekuler }\end{array}$ & $\begin{array}{l}\text { Apus tebal } \\
\text { dan apus } \\
\text { tipis } \\
\text { Nested } \\
\text { PCR }\end{array}$ & $\begin{array}{l}\text { Total : } 121 \\
\text { Pf: } 94\end{array}$ & $P k: 32$ \\
\hline Lubis et al. & 2017 & $\begin{array}{l}\text { Sumatera } \\
\text { Utara, } \\
\text { Indonesia } \\
\text { (Batubara, } \\
\text { Langkat, } \\
\text { Nias } \\
\text { Selatan) }\end{array}$ & Pasien & $\begin{array}{l}3731 \\
\text { Batubara } \\
: 1270 \\
\text { Langkat } \\
: 544 \\
\text { Nias } \\
\text { Selatan : } \\
1917\end{array}$ & $\begin{array}{l}\text { Mikroskopis } \\
\text { Molekuler }\end{array}$ & $\begin{array}{l}\text { Apus tebal } \\
\text { dan apus } \\
\text { tipis } \\
\text { Nested } \\
\text { PCR }\end{array}$ & $\begin{array}{l}\text { Batubara: } \\
117 \\
\text { Langkat : } 98 \\
\text { Nias Selatan } \\
: 397\end{array}$ & $\begin{array}{l}\text { Batubara: } \\
320 \\
\text { Langkat: } \\
182 \\
\text { Nias } \\
\text { Selatan: } \\
667\end{array}$ \\
\hline Piera et al. & 2017 & $\begin{array}{l}\text { Sabah, } \\
\text { Malaysia }\end{array}$ & Pasien & 73 & $\begin{array}{l}\text { LAMP } \\
\text { Assay }\end{array}$ & - & LAMP Assay & Pk. 50 \\
\hline
\end{tabular}

Pemeriksaan mikroskopis pada apusan darah tebal menurut WHO (2010).

$$
\text { Parasit per mikroliter darah }(\mu L)=\frac{\text { Jumlah parasit } x 8000}{200 \text { leukosit }}
$$

Apabila dalam 200 leukosit ditemukan parasit kurang dari 99 parasit, maka dilanjutkan perhitungan per 500 leukosit. Tetapi apabila dalam 200 leukosit telah ditemukan 100 atau lebih parasit maka perhitungan yang dilakukan hanya sampai per 200 leukosit (WHO, 2010)
Diagnosis $P$. knowlesi dengan pemeriksaan mikroskopis, banyak ditemukan terjadi misidentification sehingga menyebabkan kesalahan dalam diagnosis. Pemeriksaan imunokromatografi rapid diagnostic tests (RDTs) untuk $P$. knowlesi memiliki sensitivitas yang sangat rendah. RDTs yang ada hanya dapat digunakan untuk diagnosis $P$. falciparum dan $P$. vivax, sehingga bila dilakukan pemeriksaan RDTs dapat menimbulkan cross-reactive. Pemeriksaan yang saat ini sensitive dan spesifik 
untuk diagnosis $P$. knowlesi yaitu dengan pemeriksaan PCR. Pemeriksaan PCR ini tidak feasible bila digunakan pada daerah endemik dan pemeriksaan PCR ini juga membutuhkan waktu yang lama untuk penegakan diagnosis (Piere et al., 2017).

\section{Pengobatan Plasmodium knowlesi}

Pengobatan malaria akibat $P$. knowlesi tanpa komplikasi dapat diberikan dengan terapi ACT (kecuali pada ibu hamil tri semester pertama) atau dengan klorokuin. Sedangkan untuk pengobatan pada daerah yang resisten terhadap klorokuin dapat diberikan ACT saja (WHO, 2015). Studi yang telah dilakukan oleh Singh et al. (2004) di wilayah Kapit, Serawak Malaysia menyatakan bahwa pasien yang positif infeksi $P$. knowlesi diberikan pengobatan dengan kombinasi klorokuin dan primakuin.

Dosis pengobatan yang diberikan disesuaikan dengan keparahan dan tingkat parasitemianya. Penelitian lain yang dilakukan di Thailand, pasien yang mengalami mix-infection $\mathrm{Pv}_{\mathrm{v}}+\mathrm{Pk}$ diberikan pengobatan klorokuin dan primakuin, sedangkan pasien yang positif mixinfection Pf-Pk diberikan pengobatan dengan meflokuin dan artesunate (Putaporntip et al., 2009).

\section{Kesimpulan}

P. knowlesi merupakan salah satu protozoa darah yang dapat menyebabkan penyakit malaria pada monyet ekor panjang. Infeksi dari protozoa ini dapat terjadi melalui gigitan nyamuk Anopheles Leucosphyrus Group. P. knowlesi saat ini dapat menyebabkan zoonosis dan menginfeksi manusia. Prevalensi zoonosis dari infeksi ini banyak terjadi di wilayah Asia Tenggara yang secara geografis terdapat hutan hujan tropis karena pada daerah tersebut banyak populasi monyet ekor panjang. Faktor resiko dari infeksi ini yaitu petani dan pekerja kebun yang sering keluar masuk hutan atau masyarakat yang hidup didekat hutan. Diagnosis dapat dilakukan dengan pemeriksaan PCR dan pengobatan dapat diberikan dengan ACT atau kombinasi klorokuin dan primakuin.

\section{References}

Baird J. Kevin., 2009. Malaria Zoonoses. Travel Medicine and Infectious Disease $7: 269$ 277.

Baraniah M. A., 2005. Peranan karantina hewan dalam mencegah dan menangkal penyakit zoonosis. Lokakarya Nasional
Penyakit Zoonosis. Pusat Karantina Hewan.

CDC., $2018 . \quad$ Malaria. https://www.cdc.gov/malaria/about/ biology/. Diakses pada tanggal 28 Agustus 2019 Jam 15.29.

Cox-Singh J, Singh B., 2008. Knowlesi malaria : newly emergent and of public health importance? Trends Parasitol. 24 : 406410.

Grigg M.J., Cox J., William T., Jelip J., Fornace K.M., Brock P.M., Seidlein L.V., Barber B.E., Anstey N.M., Yeo T.W., Drakeley C.J., 2017. Individual-level factors associated with the risk of acquiring human Plasmodium knowlesi malaria in Malaysia: a case control study. Lancet Planet Health 1(3).

Harijanto P. N., 2000. Malaria Epidemiologi, Patogenesis, Manifestasi Klinis, dan Penanganan. Jakarta : ECG.

Lee K.S., Cox-Singh J., Singh B., 2009. Morphological features and differential counts of Plasmodium knowlesi parasites in naturally acquired human infections. Malaria Journal. 8 (73).

Lubis I. N. D., Wijaya H., Lubis M., Lubis C. P., Divis P. C. S., Beshir K. B., dan Sutherland C. J., 2017. Contribution of Plasmodium knowlesi to multispecies human malaria infection in North Sumatera, Indonesia. The Journal of Infectious Diseases 215 : 1148 1155.

Marchand R. P., Culleton R., Maeno Y., Quang N. T., Nakazawa S., 2011. Coinfection of Plasmodium knowlesi, P. falciparum, and P. vivax among humans and Anopheles dirus mosquitoes, Southern Vietnam. Emerging Infectious Diseases. 17 (7) : 1232 $-1239$.

Ministri Of Health Malaysia., 2013. Management Guidelines Of Malaria In Malaysia.

Moyes C. L., Henry A. J., Golding N., Huang Z., Singh B., Baird J. K., Newton P. N., Huffman M., Duda K. A., Drakeley C. J., Elyazar I. R. F., Anstey N. M., Chen Q., Zommers Z., Bhatt S., Gething P. W., dan Hay S. I., 2014. Defining the geographical range of the Plasmodium knowlesi reservoir. PLOS Neglected Tropical Diseases 8 (3). 
Paisal dan Indriyati L., 2014. Gambaran Plasmodium knowlesi pada manusi. Jurnal Buski 10 (2) : 87-94.

Piera K. A., Aziz A., William T., Bell D., Gonzalez I. J., Barber B. E., Anstey N. M., Grigg M. J., 2017. Detection of Plasmodium knowlesi, P. falciparum and P. vivax using loop-mediated isothermal amplification (LAMP) in a co-endemic area in Malaysia. Malaria Journal 16 (29).

Pongvongsa T., Culleton R., Ha H., Thanh L., Phongmany P., Marchand R. P., Kawai S., Moji K., Nakazawa S., Maeno Y., 2018. Human infectious with Plasmodium knowlesi on the Laos-Vietnam border. Tropical Medicine and Health. 46 (33).

Putaporntip C., Hongsrimuang T., Seethamchai S., Kobasa T., Limtkittikul K., Cui L., Jongwutiwes S., 2009. Differential prevalence of Plasmodium infections and cryptic Plasmodium knowlesi malaria in human in Thailand. The Journal of Infectious Disease. 199 : 11431150.

Sermwittayawong N., Singh B., Nishibuchi M., Sawangjaroen N., Vuddhakul V., 2012. Human Plasmodium knowlesi infection in Ranong province, southwestern border of Thailand. Malaria Journal. 11 (36).
Siner A., Liew S., Kadir K. A., Mohamad D. S. A., Thomas F. K., Zulkarnaen M., and Singh B., 2017. Absence of Plasmodium inui and Plasmodium cynomolgi, but detection of Plasmodium knowlesi and Plasmodium vivax infection in asymptomatic humans in the Betong division of Sarawak Malaysian Borneo. Malaria Journal 16 (416).

Singh B., Sung L. K., Matusp A., Radhakrishnan A., Shamsul S. SG., Cox-Singh J., Thomas A., Conway D. J., 2004. A large focus of naturaaly acquired Plasmodium knowlesi infections in human beings. The Lancet. 363 (9414) : 1017 - 1024.

Vythilingam I., NoorAzian Y. M., Huat T. C., Jiran A. I., Yusri Y. M., Azahari A. H., NorParina I., NoorRain A., LokmanHakim S., 2008. Plasmodium knowlesi in human, macaques, and mosquitoes in peninsular Malaysia. Parasites \& Vectors. 1 (26).

WHO., 2010. Basic Malaria Microscopy $2^{\text {nd }}$ ed. Geneva : WHO Press.

WHO., 2015. Guidelines for the treatment of malaria 3th ed. Geneva : WHO Press

Zaman, Viqar., 1997. Atlas Parasitologi Kedokteran. Jakarta : Hipokrates.

Zaw M. T., Lin Z., 2019. Human Plasmodium knowlesi infections in South-East Asian countries. Journal of Microbiology, Immunology, dan Inceftion. 